\title{
ANALISIS KESALAHAN SISWA MTS KELAS IX DI BANDUNG BARAT DALAM MENYELESAIKAN SOAL MATERI STATISTIKA
}

\author{
Hanapiah Sara Juliana ${ }^{1}$, Luvy Sylviana Zanthy ${ }^{2}$ \\ ${ }^{1,2}$ IKIP Siliwangi, Jl Terusan Jendral Sudirman Cimahi \\ Hanafiahsyara6@gmail.com
}

\begin{abstract}
This study aims to analyze the errors of MTs students in solving statistical material problems. The research method used in this study is the description method. The study was conducted with the research subjects of 25 students of class IXc Nurul Iman Sindangkerta in the 2019/2020 school year. The test questions were 5 questions. The results showed that the students' mathematical abilities in terms of overall results were classified as low and there were 1 indicators that answered a lot correctly, which were indicators that correctly identified a problem, which was $65 \%$. And it consists of 1 indicator that enters a lot of answers which is $81 \%$ with indicators explaining the steps or ideas of a problem solving clearly and precisely into written form.
\end{abstract}

Keywords: Error Analysis, Statistics

\begin{abstract}
Abstrak
Penelitian ini bertujuan untuk menganalisis kesalahan siswa MTs dalam memecahkan soal materi statistika. Metode penelitian yang digunakan dalam penelitian ini adalah metode deskripsi. Penelitian dilakukan dengan subjek penelitiannya 25 siswa MTs kelas IXc Nurul Iman Sindangkerta tahun ajaran 2019/2020. Soal tes yang diberikan sebanyak 5 soal uraian. Hasil penelitian menunjukan bahwa kemampuan matematik siswa ditinjau dari hasil keseluruhan tergolong rendah dan terdapat 1 indikator yang banyak menjawab benar yaitu untuk indikator mengidentifikasi suatu masalah dengan tepat.yakni sebesar 65\%. Dan terdiri 1 indikator yang masuk banyak menjawab salah yakni $81 \%$ dengan indikator menjelaskan langkah atau ide dari suatu penyelesaian persoalan secara jelas dan tepat ke dalam bentuk tulisan.
\end{abstract}

Kata kunci: Analisis Kesalahan, Statistika

\section{PENDAHULUAN}

Pendidikan mempunyai peranan sangat penting bagi kehidupan manusia dimana dengan pendidikan semua manusia akan mempunyai arah hidup untuk masa depannya (Akbar, et. al, 2018). Dengan itu, pendidikan tidak sekedar mempersiapkan siswa untuk suatu jabatan atau profesi tapi bagaimana pendidikan dapat menyiapkan siswa agar bisa menyelesaikan masalah apapun yang akan dihadapinya. Di dalam undang-undang pendidikan tahun 2003 dijelaskan fungsi dari pendidikan nasional yaitu bisa mengembangkan kemampuan siswa dan akan membentuk suatu watak yang berilmu, mandiri, kreatif dalam rangka untuk menncerdaskan suatu kehidupan bangsa dan menjadi warga yang bertanggung jawab dan demokratis.

Menurut (Aritonang 2008) "Belajar yakni suatu proses untuk dapat memperoleh sebuah perubahan dalam tingkah laku sesuai pengalaman individunya sendiri”. Menurut (Hamalik, 2007: 3637) berpendapat bahwa "Belajar yaitu suatu perubahan dalam tingkah laku individu melalui lingkungan atau interaksi". Dan menurut Abdillah (Firmansyah, 2017) menyatakan bahwa " belajar ialah suatu perubahan dalam tingkah laku baik pengalaman ataupun melalui latihan yang menyangkut aspek afektif, kognitif, dan psikomotorik untuk mencapai suatu tujuan tertentu".

Matematika sebagai pelayan ilmu, dimana matematika melayani dan digunakan dalam berbagai bidang dan digunakan dalam kehidupan sehari-hari. (Sugandi \& Akbar, 2019; Isnaeni, et. al., 2018; Wiliawanto, et. al., 2019; Akbar, et. al., 2018), matematika diajarkan sejak sekolah dasar 
hingga perguruan tinggi secara formal maupun nonformal (Bernard, et.al., 2019) karena matematika ini di anggap suatu pelajaran yang sangat esensial bagi pendidikan saat ini untuk meningkatkan kualitas pendidikan dan melahirkan generasi emas bagi Indonesia, Matematika juga dapat dibentuk dari pikiran-pikiran siswa yang berhubungan dengan idea, proses, dan penalaran. Faktor pengajaran dapat mempengaruhi keberhasilan tingkat kemajuan siswa (Bernard, et.al, 2019). Tetapi banyak juga yang beranggapan matematika itu sulit untuk dipelajari seiring dengan pengamatan (Siswanto, et.al, 2018). Siswa sering tidak dapat menyelesaikan soal-soal matematika karena kemampuan pemecahan masalah yang mereka miliki sangat rendah.

Pembelajaran yang ada selama ini masih banyak yang didominasi guru saja, sedangkan siswa hanya Datang, Duduk, Dengar, Catat, dan Hafal atau yang dikenal dengan istilah D3CH (Bernard, 2014; Insani, et. al., 2019). Padahal menurut Buranda, \& Bernard, (2019) matematika sangat penting karena tidak terlepas kaitan dengan kehidupan sehari-hari. misalnya dalam konsep statistika. Penanaman konsep yang benar dan motivasi siswa yang tinggi tentu menjadi faktor yang harus diperhatikan (Sunaryo, 2019). Dengan konsep ini salah satunya kita dapat menghitung jumlah penduduk, menghitung naik turunnya harga barang dengan simbol grafik, tabel, dan diagram. Statistika menjadi materi pembelajaran yang harus dipelajari dalam pembelajaran matematika saat ini, salah satunya dijenjang Sekolah Menengah Pertama (SMP/MTs) dimana siswa ditekankan pentingnya pengetahuan pemahaman statistik di dalam kehidupan sehari-hari, dengan itu peneliti akan menganalisis kesalahan siswa di materi pembelajaran statistika, terutama dalam menyelesaikan soal di kehidupan sehari-hari. Oleh dasar itulah peneliti mencoba menganalisis bagaimana kesalahan siswa dalam mengerjakan soal materi Statistika di SMP.

\section{METODE}

Jenis metode penelitian ini yaitu deskriftif kualitatif. Penelitian ini dilaksanakan di salah satu Madrasah Tsanawiah Nurul Iman Sindangkerta yang berada di Bandung Barat dengan data yang di peroleh dari 20 siswa di kelas VIII tahun ajaran 2019/2020. Untuk teknik pengumpulan data pada penelitian ini tentang kesalahan siswa dalam mengerjakan soal materi statistika yang berasal dari hasil tes kemampuan siswa dalam memahami materi statistika. Dalam penelitian ini memiliki tiga tahap prosedur, yakni: tahap persiapan, tahap pelaksanaan dan tahap analisis.

Adapun cara untuk menganalisis suatu kesalahan yang dilakukan siswa dalam penyelesaian soal statistika mengacu kepada teori analisis kesalahan Newman dimana menurut Newman (Clement, 1980) terdapat lima tipe kesalahan siswa dalam mengerjakan soal matematika, yaitu: 1) kesalahan membaca; 2) kesalahan dalam memahami; 3) kesalahan dalam transformasi, atau kesalahan siswa yang belum bisa mengubah soal ke bentuk matematika dengan benar; 4) kurangnya keterampilan dalam perhitungan;eringnya kesalahan dalam notasi sehingga menjadi kesalahan dalam peroses penyelesaian. Presentase dalam penelitian ini yang menilai banyaknya kesalahan dari masing-masing 
Analisis Kesalahan Siswa Mts Kelas Ix Di Bandung Barat Dalam Menyelesaikan Soal Materi Statistika, Hanapiah Sara Juliana, Luvy Sylviana Zanthy

kesalahan merujuk pada Nurkanca \& Sunarta (Farida, Alauzi, \& Zanthy, 2019) Kriteria presentase banyaknya kesalahan.

Tabel 1.

Kriteria Presentase Banyaknya Kesalahan

\begin{tabular}{l|c}
\hline Presentase $(\mathrm{P})$ & Kriteria \\
\hline $90,00 \leq \mathrm{P} \leq 100$ & Sangat Tinggi \\
\hline $80,00 \leq \mathrm{P}<90,00$ & Tinggi \\
\hline $65,00 \leq \mathrm{P}<80,00$ & Sedang \\
\hline $55,00 \leq \mathrm{P}<65,00$ & Rendah \\
\hline $\mathrm{P}<55,00$ & Sangat Rendah \\
\hline
\end{tabular}

HASIL

Setelah siswa diberikan tes tersebut, peneliti akan menganalisis hasil dari setiap jawaban siswa dan data-data tersebut diinterpretasikan kedalam bentuk deskripsi sebagai gambaran hasil dari penelitian. Hasil dari perolehan skor siswa pada setiap indikator dapat dilihat di tabel 2.

Tabel 2.

Hasil Perolehan Skor Siswa Setiap Butir Soal

\begin{tabular}{|c|c|c|c|c|c|c|c|c|c|}
\hline No & $\begin{array}{l}\text { Kode } \\
\text { Siswa }\end{array}$ & $\begin{array}{c}\text { Soal } 1 \\
\text { (15) }\end{array}$ & $\begin{array}{c}\text { Soal } 2 \\
(30)\end{array}$ & $\begin{array}{c}\text { Soal 3 } \\
\text { (15) }\end{array}$ & $\begin{array}{c}\text { Soal } 4 \\
(25)\end{array}$ & $\begin{array}{c}\text { Soal } 5 \\
(15)\end{array}$ & $\begin{array}{l}\text { Total } \\
\text { Nilai }\end{array}$ & Persentase & KKM \\
\hline 1 & S1 & 5 & 5 & 5 & 5 & 5 & 25 & $25 \%$ & 75 \\
\hline 2 & S2 & 5 & 5 & 15 & 5 & 10 & 40 & $40 \%$ & 75 \\
\hline 3 & S3 & 5 & 5 & 5 & 10 & 10 & 35 & $35 \%$ & 75 \\
\hline 4 & S4 & 10 & 5 & 15 & 10 & 15 & 55 & $55 \%$ & 75 \\
\hline 5 & S5 & 5 & 5 & 5 & 10 & 5 & 30 & $30 \%$ & 75 \\
\hline 6 & S6 & 5 & 5 & 10 & 5 & 15 & 40 & $40 \%$ & 75 \\
\hline 7 & S7 & 5 & 5 & 5 & 5 & 15 & 35 & $35 \%$ & 75 \\
\hline 8 & S8 & 5 & 10 & 10 & 10 & 5 & 40 & $40 \%$ & 75 \\
\hline 9 & S9 & 5 & 5 & 5 & 5 & 10 & 30 & $30 \%$ & 75 \\
\hline 10 & S10 & 5 & 5 & 5 & 5 & 15 & 35 & $35 \%$ & 75 \\
\hline 11 & S11 & 5 & 5 & 10 & 5 & 5 & 30 & $30 \%$ & 75 \\
\hline 12 & S12 & 5 & 5 & 10 & 10 & 10 & 40 & $40 \%$ & 75 \\
\hline 13 & S13 & 5 & 5 & 10 & 10 & 5 & 35 & $35 \%$ & 75 \\
\hline 14 & S14 & 5 & 5 & 10 & 10 & 5 & 35 & $35 \%$ & 75 \\
\hline 15 & S15 & 5 & 5 & 10 & 5 & 10 & 35 & $35 \%$ & 75 \\
\hline 16 & S16 & 10 & 5 & 10 & 10 & 10 & 45 & $45 \%$ & 75 \\
\hline 17 & S17 & 5 & 5 & 15 & 10 & 15 & 50 & $50 \%$ & 75 \\
\hline 18 & S18 & 5 & 5 & 5 & 5 & 10 & 30 & $30 \%$ & 75 \\
\hline 19 & S19 & 10 & 5 & 10 & 10 & 15 & 50 & $50 \%$ & 75 \\
\hline 20 & S20 & 5 & 15 & 5 & 10 & 5 & 40 & $40 \%$ & 75 \\
\hline \multicolumn{2}{|c|}{ Jumlah } & 115 & 115 & 175 & 155 & 195 & 755 & & \\
\hline
\end{tabular}




\begin{tabular}{|c|c|c|c|c|c|c|c|c|}
\hline $\mathrm{P}$ benar $(\&)$ & $38 \%$ & $19 \%$ & $58 \%$ & $31 \%$ & $65 \%$ & $22 \%$ & & \\
\hline $\mathrm{P} \operatorname{salah}(\%)$ & $62 \%$ & $81 \%$ & $42 \%$ & $69 \%$ & $35 \%$ & & & \\
\hline
\end{tabular}

Dari data table 2 diatas dapat dilihat bahwa semua nilai siswa dibawah KKM dengan rata-rata nilai terendah ada di soal nomor 2 sebesar 19\% dan tertinggi di soal nomor 5 sebesar $65 \%$. Untuk analisis lebih lanjut dapat dilihat pada Tabel 3 berikut:

Tabel 3

Hasil Analisis Matematik Siswa dalam Menyelesaikan Soal Statistika

\begin{tabular}{|l|l|c|c|}
\hline No & \multicolumn{1}{|c|}{ Indikator } & Benar & Salah \\
\hline 1. & $\begin{array}{l}\text { Membuat suatu informasi dengan menggunakan tabel distribusi secara } \\
\text { tepat. }\end{array}$ & $38 \%$ & $62 \%$ \\
\hline 2. & $\begin{array}{l}\text { Menjelaskan langkah atau ide dari suatu penyelesaian persoalan secara } \\
\text { jelas dan tepat ke dalam bentuk tulisan. }\end{array}$ & $19 \%$ & $81 \%$ \\
\hline 3. & $\begin{array}{l}\text { Membuat kembali suatu informasi menggunakan diagram batang secara } \\
\text { tepat dan menuliskan suatu ide penyelesaian dengan tepat. }\end{array}$ & $58 \%$ & $42 \%$ \\
\hline 4. & $\begin{array}{l}\text { Menuliskan apa yang diketahui dengan menggunakan rumus } \\
\text { matematika. }\end{array}$ & $31 \%$ & $69 \%$ \\
\hline 5. & Mengidentifikasi suatu masalah dengan tepat. & $65 \%$ & $35 \%$ \\
\hline
\end{tabular}

Pada tabel di atas, menunjukan bahwa suatu kemampuan matematik siswa pada materi statistika dengan kategori membuat suatu informasi dengan menggunakan tabel distribusi secara tepat yang menjawab benar 38\% dan yang menjawab salah $62 \%$ dengan kriteria presentase (rendah). Menjelaskan langkah atau ide dari suatu penyelesaian persoalan secara jelas dan tepat dalam bentuk tulisan, terdapat $19 \%$ yang menjawab benar dan $81 \%$ yang menjawab salah dengan kriteria (tinggi). Dalam membuat kembali suatu informasi menggunakan diagram batang secara tepat dan menuliskan suatu ide penyelesaian dengan tepat terdapat $58 \%$ yang menjawab benar dan $42 \%$ yang menjawab salah dengan kriteria (sangat rendah). Dalam menuliskan apa yang diketahui dengan menggunakan rumus matematika terdapat $31 \%$ yang menjawab benar dan $69 \%$ yang menjawab salah dengan kriteria (rendah) . Dan yang terakhir mengidentifikasi suatu masalah dengan tepat terdapat $65 \%$ yang menjawab benar dan 35\% yang menjawab salah dengan kriteria (sangat rendah).

Berikut dibawah ini, analisis kesalahan pada jawaban siswa. Data nilai 20 siswa kelas 8 pada ulangan harian matematika :

\section{Tabel 4.}

Soal no.1 (Membuat suatu informasi dengan menggunakan tabel distribusi secara tepat)

\begin{tabular}{|c|l|c|}
\hline NO & NAMLA & NILAI \\
\hline 1 & Rina & 7 \\
\hline 2 & Rini & 6 \\
\hline 3 & Azis & 8 \\
\hline 4 & Reni & 9 \\
\hline 5 & Ani & 6 \\
\hline 6 & Ica & 7 \\
\hline 7 & Puii & 8 \\
\hline 8 & Tri & 9 \\
\hline 9 & Nasyuva & 4 \\
\hline 10 & Shafa & 6 \\
\hline
\end{tabular}

\begin{tabular}{|c|l|c|}
\hline NO & NAMA & NILAI \\
\hline 11 & Resti & 9 \\
\hline 12 & Edi & 8 \\
\hline 13 & Aat & 8 \\
\hline 14 & Doyok & 6 \\
\hline 15 & Dadan & 6 \\
\hline 16 & Tata & 9 \\
\hline 17 & Nita & 7 \\
\hline 18 & Riri & 5 \\
\hline 19 & Taufan & 7 \\
\hline 20 & Farhan & 7 \\
\hline
\end{tabular}

\begin{tabular}{|c|l|c|}
\hline NO & NAMI & NILAI \\
\hline 21 & Kiki & 4 \\
\hline 22 & Eebri & 8 \\
\hline 23 & Sani & 7 \\
\hline 24 & Tari & 8 \\
\hline 25 & Suli & 9 \\
\hline 26 & Dewsi & 6 \\
\hline 27 & Lilis & 10 \\
\hline 28 & Santi & 8 \\
\hline 29 & Nia & 7 \\
\hline 30 & Listya & 10 \\
\hline
\end{tabular}


Analisis Kesalahan Siswa Mts Kelas Ix Di Bandung Barat Dalam Menyelesaikan Soal Materi Statistika, Hanapiah Sara Juliana, Luvy Sylviana Zanthy

Sajikan kembali data di atas dalam bentuk tabel distribusi, agar mudah diketahui berapakah banyaknya siswa yang memiliki nilai tertentu ! dan jika siswa yang lulus adalah yang memiliki nilai di atas rata-rata, maka berapa banyak siswa yang lulus?

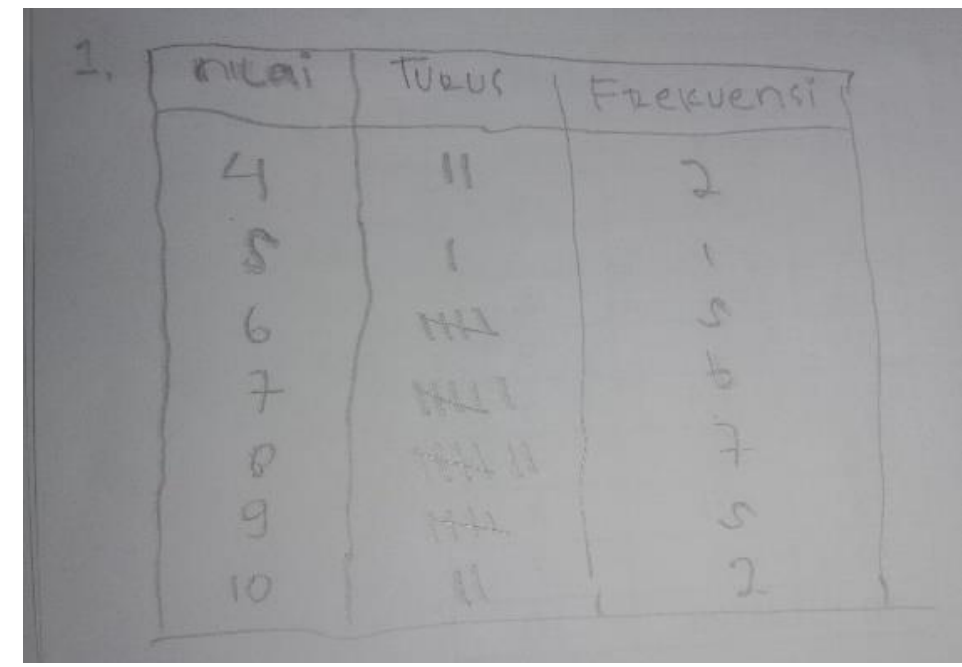

Gambar 1. Jawaban siswa

Pada soal no 1, dengan indikator membuat suatu informasi dengan menggunakan tabel distribusi secara tepat beberapa siswa hanya mampu menjawab satu poin yaitu tabel distribusi dengan tepat hanya saja siswa melakukan kesalahan dipoin yang ke dua dimana siswa harus menentukan rata-rata dari data tersebut, bahkan siswa merasa tidak mampu menjawab poin ke dua sehingga tidak melanjutkan jawabannya.

Suatu sekolah melakukan pencatatan tentang pendapatan orang tua siswa kelas 8 sebanyak 140 siswa. Pencatatan dilakukan untuk menentukan banyaknya siswa yang berhak memperoleh dana bantuan. Data yang diperoleh disajikan dalam diagram lingkaran sebagai berikut:

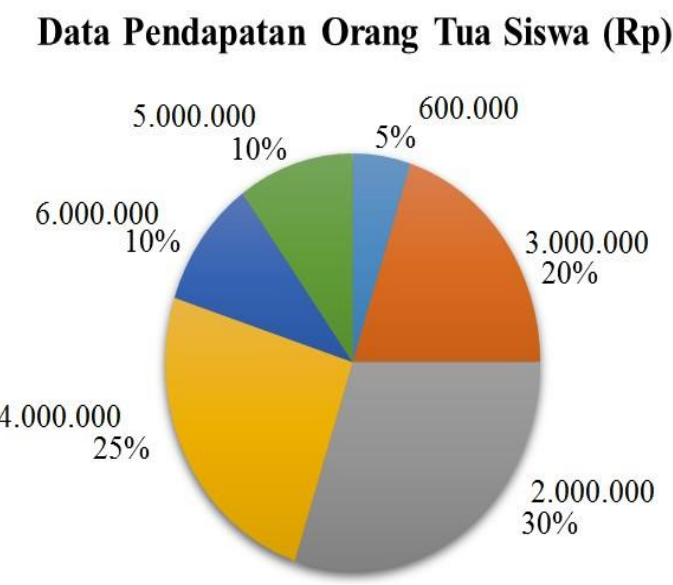

Gambar 2. Soal no 2 (Menjelaskan langkah atau ide dari suatu penyelesaian persoalan secara jelas dan tepat ke dalam bentuk tulisan) 
Hitunglah banyaknya orang tua dari masing-masing data pendapatan pada diagram lingkaran diatas !

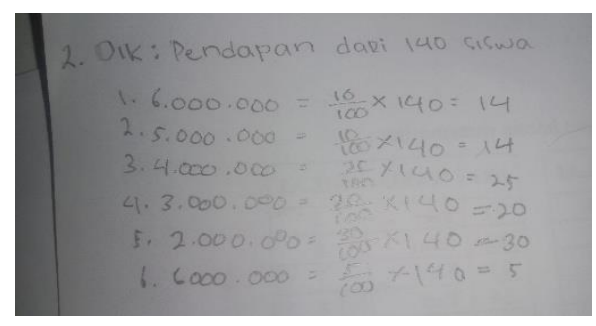

Gambar 3. Jawaban siswa

Pada gambar 4, dengan indikator Menjelaskan langkah atau ide dari suatu penyelesaian persoalan secara jelas dan tepat ke dalam bentuk tulisan. Beberapa siswa mampu menjawab soal dengan tepat hanya saja siswa kurang teliti sehingga beberapa jawabannya mengalami kesalahan. Diberikan data tentang penjualan buku tulis jenis A di koperasi sekolah pada tahun 2016 yang disajikan dalam tabel berikut :

\section{Tabel 5.}

Soal no 3 (Membuat kembali suatu informasi menggunakan diagram batang secara tepat dan menuliskan suatu ide penyelesaian dengan tepat)

\begin{tabular}{|c|c|c|c|c|c|c|c|c|c|c|c|c|}
\hline Bulan Ke & 1 & 2 & 3 & 4 & 5 & 6 & 7 & 8 & 9 & 10 & 11 & 12 \\
\hline $\begin{array}{c}\text { Banyak } \\
\text { Buku }\end{array}$ & 50 & 22 & 30 & 15 & 16 & 24 & 25 & 28 & 19 & 26 & 18 & 30 \\
\hline
\end{tabular}

Sajikan data tersebut berdasarkan diagram yang kamu pilih. Dan amati, apakah jumlah penjualan buku selalu naik? Atau selalu turun? Berikan kesimpulan!

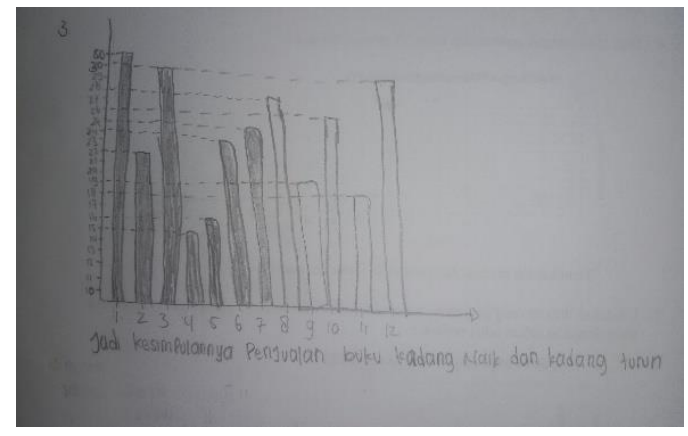

Gambar 4. Jawaban siswa

Pada gambar 6, dengan indikator membuat kembali suatu informasi menggunakan diagram batang secara tepat dan menuliskan suatu ide penyelesaian dengan tepat. Pada indikator ini banyak siswa yang mampu menjawab soal dengan benar, karena di dalam soal tertera sangat jelas bahwa setiap pembelian buku mengalami naik turun. Diberikan data tentang penjualan buku tulis jenis A di koperasi sekolah pada tahun 2016 yang disajikan dalam tabel berikut: 
Data Penjualan Buku Tahun 2016

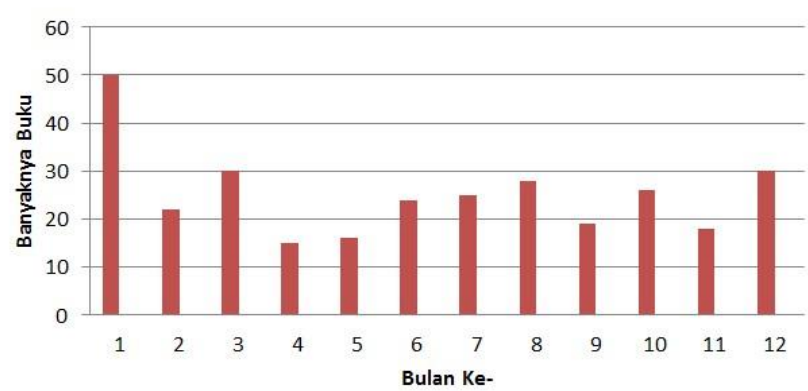

Gambar 5. Soal no 4 (Menuliskan apa yang diketahui dengan menggunakan rumus matematika)

Jika keuntungan rata-rata yang diperoleh setiap bulannya Rp. 1000.000 berapa keuntugkan dari setiap buku? Jelaskan! (tuliskan angka diketahui dan ditanyakan).

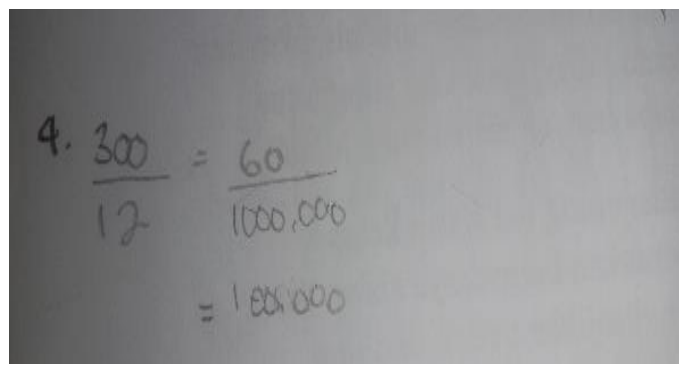

Gambar 6. Jawaban siswa

Pada gambar 8, dengan indikator menuliskan apa yang diketahui dengan menggunakan rumus matematika. Dalam indikator ini masih banyak siswa yang melakukan kesalahan adapula siswa yang sudah padam dengan maksud soal akan tetapi lagi-lagi siswa kurang teliti dalam menyelesaikan soal yang diberikan Terdapat nilai matematika kelas VIII dari 13 siswa dengan nilai: $7,5,6,8,6,6,7,5,10,8,7,9,7$.

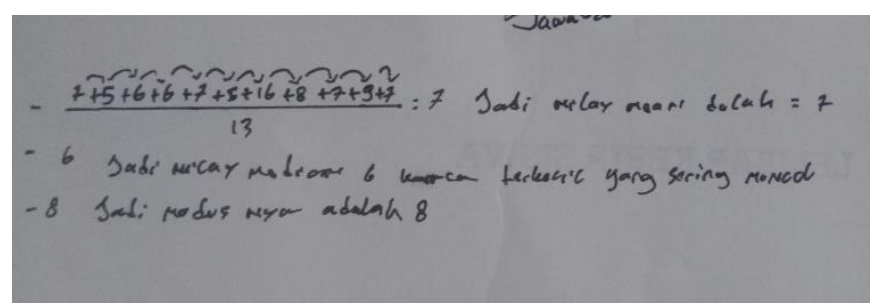

Gambar 7. Jawaban Siswa

Pada gambar 7, dengan indikator mengidentifikasi suatu masalah dengan tepat. Dalam indikator ini masih banyak siswa yang menjawab salah dikarenakan masih kurangnya pemahaman matematik siswa dalam menyelesaikan soal statistika. 


\section{KESIMPULAN}

Uraian tentang kesalahan siswa dalam materi statistika pada siswa MTS kelas VIII berdasarkan hasil pengamatan indikator pencapaian kompetensi dapat disimpulkan bahwa terdapat 1 indikator yang yang banyak menjawab benar yaitu pada indikator mengidentifikasi suatu masalah dengan tepat sebesar 65\% siswa. dan kesalahan terbanyak siswa terdapat pada indikator menjelaskan langkah atau ide dari suatu penyelesaian persoalan secara jelas dan tepat ke dalam bentuk tulisan sebesar $81 \%$ siswa menjawab salah. Secara keseluruhan siswa masih kesulitan dalam menyelesaikan soal materi statistika, hal ini dapat dilihat dari rata-rata nilai keseluruhan siswa dibawah nilai 50 yang artinya jauh dibawah KKM yaitu nilai 75. Maka dapat disimpulkan bahwa kemampuan matematik siswa dalam menyelesaikan soal materi statistika masih dalam kategori rendah serta siswa banyak melakukan kesalahan menjawab soal dalam indikator menjelaskan langkah atau ide dari suatu penyelesaian persoalan secara jelas dan tepat ke dalam bentuk tulisan.

\section{DAFTAR PUSTAKA}

Akbar, P., Hamid, A., Bernard, M., \& Sugandi, A. I. (2018). Analisis kemampuan pemecahan masalah dan disposisi matematik siswa kelas xi sma putra juang dalam materi peluang. Jurnal Cendekia: Jurnal Pendidikan Matematika, 2(1), 144-153.

Aritonang, K. T. (2008). Minat dan motivasi dalam meningkatkan hasil belajar siswa. Jurnal Pendidikan Penabur, 7(10), 11-21.

Aryanto, Y., Cahya, \& Setiawan, W. (2019). Implementasi geogebra pada materi bangun ruang sisi lengkung untuk meningkatkan hasil belajar matematik siswa smp. Journal on Education, 01(03), $525-530$.

Bernard, M. (2014). Pengaruh pembelajaran dengan menggunakan multimedia macromedia falsh terhadap kemampuan penalaran matematik. In Prosiding Seminar Nasional Pendidikan Matematika Program Pasca Sarjana STKIP Siliwangi Bandung (Vol. 1, pp. 425-429).

Bernard, M., Akbar, P., Ansori, A., \& Filiestianto, G. (2019, October). Improve the ability of understanding mathematics and confidence of elementary school students with a contextual approach using VBA learning media for Microsoft Excel. In Journal of Physics: Conference Series (Vol. 1318, No. 1, p. 012035). IOP Publishing.

Bernard, M., Sumarna, A., Rolina, R., \& Akbar, P. (2019, October). Development of high school student work sheets using VBA for microsoft word trigonometry materials. In Journal of Physics: Conference Series (Vol. 1315, No. 1, p. 012031). IOP Publishing.

Buranda, M. S., \& Bernard, M. (2019). Analisis Kemampuan Pemecahan Masalah Matematik Materi Lingkaran Siswa Smp Berdasarkan Gender. JPMI (Jurnal Pembelajaran Matematika Inovatif), 2(1), 33-40.

Depdiknas. 2003. Undang-Undang Republik Indonesia Nomor 20 Tahun 2003 Tentang Sistem Pendidikan Nasional. Jakarta: Depdiknas.

Farida, E., Alauzi, F. A., \& Zanthy, L. S. (2019). Analisis koneksi matematis siswa dan kepercayaan diri siswa smp. Journal on Education, 01(04), 688-695.

Firmansyah, M. A. (2017). Analisis Hambatan Belajar Mahasiswa Pada Mata Kuliah Statistika. $\begin{array}{llll}\text { Jurnal Penelitian Dan Pembelajaran } & \text { Matematika, }\end{array}$ 
Analisis Kesalahan Siswa Mts Kelas Ix Di Bandung Barat Dalam Menyelesaikan Soal Materi Statistika, Hanapiah Sara Juliana, Luvy Sylviana Zanthy

https://doi.org/10.30870/jppm.v10i2.2036

Hamalik, Oemar. 2007. Kurikulum dan Pembelajaran. Jakarta: Bumi Aksara.

Insani, S. U., \& Akbar, P. (2019, October). Development of Open-Ended Based Mathematics Problem to Measure High-Level Thinking Ability. In Journal of Physics: Conference Series (Vol. 1315, No. 1, p. 012047). IOP Publishing.

Isnaeni, S., Ansori, A., Akbar, P., \& Bernard, M. (2018). MATERI PERSAMAAN DAN PERTIDAKSAMAAN LINEAR SATU. 01(02), 309-316

Khadijah, I. N. A., Maya, R., \& Setiawan, W. (2018). Analisis Kemampuan Komunikasi Matematis Siswa Smp Pada Materi Statistika. JPMI Jurnal Pembelajaran Matematika Inovatif, 1(6), 10951104.

Puskur (2002). Kurikulum dan Hasil Belajar. Kompetensi Dasar Mata Pelajaran Matematika Sekolah Dasar dan Madrasah Ibtidaiyah. Jakarta: Balitbang Depdiknas.

Siswanto, R. D., Dadan, D., Akbar, P., \& Bernard, M. (2018). Penerapan Model Pembelajaran Kooperatif Tipe Auditorial, Intelectually, Repetition (Air) Untuk Meningkatkan Pemecahan Masalah Siswa Smk Kelas XI. Journal on Education, 1(1), 66-74.

Sugandi, A. I., \& Akbar, P. (2019). Efektivitas Penerapan Strategi React Terhadap Kemampuan Koneksi Matematis dan Self-Efficacy Siswa SMP. Jurnal Cendekia: Jurnal Pendidikan Matematika, 3(2), 431-436.

Sunaryo, A. (2019). Penggunaan Media Pembelajaran Geogebra Terhadap Hasil Belajar Siswa Tentang Materi Program Linier Kelas X. Journal on Education, 2(1), 96-103.

Wiliawanto, W., Bernard, M., Akbar, P., \& Sugandi, A. I. (2019). Penerapan Strategi Pembelajaran Aktif Question Student Have Untuk Meningkatkan Kemampuan Berpikir Kritis Matematik Siswa SMK. Jurnal Cendekia: Jurnal Pendidikan Matematika, 3(1), 139-148. 